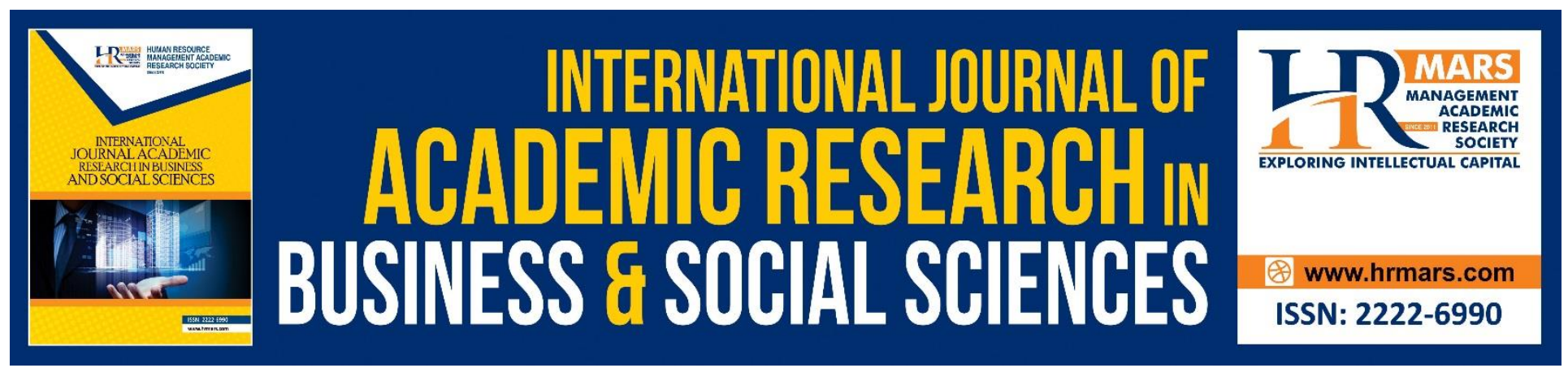

\title{
Effects of Green Skills Module in Design and Technology Subjects on The Student's Knowledge in Primary School
}

Amarumi Alwi, Arasinah Kamis, Bushra Limuna Hj Ismail

To Link this Article: http://dx.doi.org/10.6007/IJARBSS/v8-i11/5343

DOI: $10.6007 /$ IJARBSS/v8-i11/5343

Received: 29 Oct 2018, Revised: 30 Nov 2018, Accepted: 03 Nov 2018

Published Online: 06 Dec 2018

In-Text Citation: (Alwi, Kamis, \& Ismail, 2018)

To Cite this Article: Alwi, A., Kamis, A., \& Ismail, B. L. H. (2018). Effects of Green Skills Module in Design and Technology Subjects on The Student's Knowledge in Primary School. International Journal of Academic Research in Business and Social Sciences, 8(11), 1701-1712.

Copyright: (C) 2018 The Author(s)

Published by Human Resource Management Academic Research Society (www.hrmars.com) This article is published under the Creative Commons Attribution (CC BY 4.0) license. Anyone may reproduce, distribute, translate and create derivative works of this article (for both commercial and non-commercial purposes), subject to full attribution to the original publication and authors. The full terms of this license may be seen at: $\underline{\text { http://creativecommons.org/licences/by/4.0/legalcode }}$

Vol. 8, No. 11, 2018, Pg. 1701 - 1712

http://hrmars.com/index.php/pages/detail/IJARBSS

JOURNAL HOMEPAGE

Full Terms \& Conditions of access and use can be found at http://hrmars.com/index.php/pages/detail/publication-ethics 


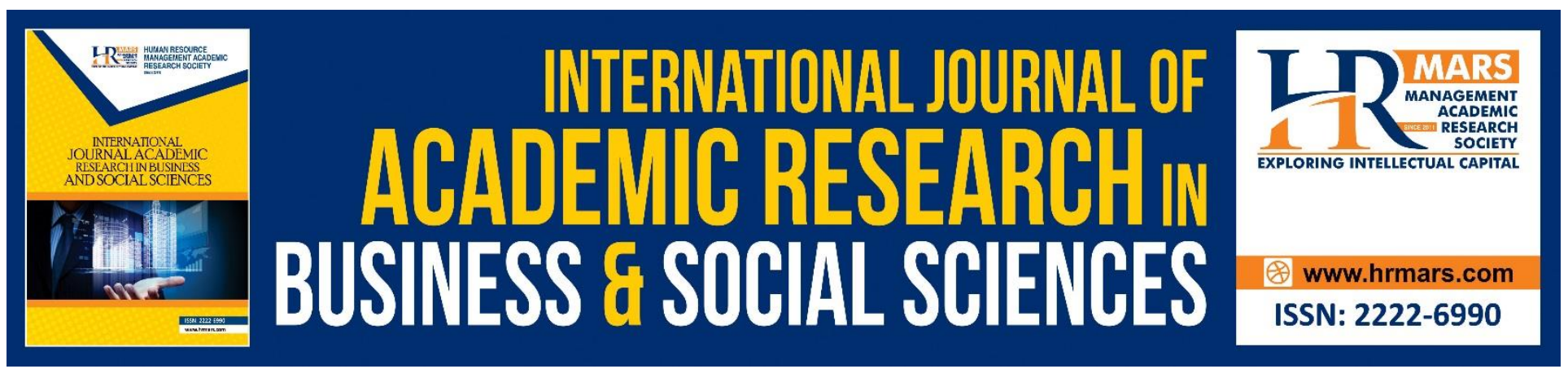

\title{
Effects of Green Skills Module in Design and Technology Subjects on The Student's Knowledge in Primary School
}

\author{
Amarumi Alwi, Arasinah Kamis, Bushra Limuna Hj Ismail \\ Faculty of Technical and Vocational Education, Universiti Pendidikan Sultan Idris, Malaysia
}

\begin{abstract}
Green skills are practical approaches that will help preserve and conserve the environment. This study aims to investigate the effect of using the Green Skills Module (Gs) in Design and Technology (DnT) subjects in the primary school. This is a quantitative study that used Quasi Experimental method of pre- and post-test. The study used cluster sampling to select 62 students in an elementary school. 32 students in the treatment group used the Gs Module while 30 pupils in the control group did not use the Gs Module during a study period of nine weeks. The data were collected through pre-and posttest and analysed using $t$-test and SPANOVA. The results of the $t$-test show that there was no significant difference in pre-knowledge test on green skills for treatment groups and control groups, indicating the level of students' knowledge before using the module was at the same level, $t=(-1.083)$ $p>0.785$. The findings of SPANOVA show significant differences in $p<0.05$ to knowledge after using Gs Module. Thus, green skills can be integrated into skills-based subjects such as DnT in providing knowledge on green skills.
\end{abstract}

Keywords: Green Skills, Module, Knowledge, Design and Technology.

\section{Introduction}

Green Technology Master Plan (GTMP) 2017-2030 was introduced by the Government of Malaysia as one of the strategic plans for the development of green technology to produce a low-carbon economy and utilise resources efficiently. This master plan is also known as the National Transformation 2050 or TN50 initiative, which aims to put Malaysia among the world's top countries in economic development, people's prosperity and innovation by 2050. Green technology is also closely linked with green skills and green jobs (Majumdar, 2010; Mustapha, 2015). Hence, the integration of green skills into the education system is crucial in efforts to produce both a skilled and environmentally conscious workforce. 
The TN50 initiative is also in line with the Sustainable Development Goals (SDGs, 2015) introduced in Agenda 2030 by the United Nations, which spells out 17 goals that all nations must achieve by 2030. Among the goals stated are as the following: quality education; clean water and sanitation; and sustainable cities and communities. In particular, the goal of quality education is that by 2030 , all students will acquire the necessary knowledge and skills to promote sustainable development, among others, through education for sustainable development and sustainable lifestyles.

Hence, it is fitting that Technical and Vocational Education plays a role in educating students to be aware of the environment through a more sustainable curriculum. Green technology integration in the PTV curriculum is of interest to the nation (Kamis, Alwi, Hj Ismail, Zakaria, \& Nur Yunus, 2017; Kamis, Mustapha, Abdul Wahab, \& Hj. Ismail, 2016; Pavlova \& Huang, 2013). It is very useful in ensuring the nation's education philosophy can be realised in line with the national policy of green technology. Green technology is a continuous effort towards furthering the potential of individuals in a comprehensive and integrated way to produce balanced and harmonious people in the intellectual, spiritual, emotional and physical domains based on belief in God and obedience (Siti Nor Syazwani, Mohd Safarin, \& Muhammad Sukri, 2012).

\section{Literature Review}

In general, environmental education has long been introduced in the syllabus of schools in science subjects. Moreover, teachers are encouraged to highlight environmental elements across the curriculum. However, despite the fact that environmental education has been carried out across the curriculum for a long time, environmental awareness is still low (Ahmad, Mustafa, Abd. Hamid, \& Abdul Wahab, 2011; Ahmad \& Mustafa, 2011). In fact, Mukoni (2013) found that environmental education knowledge received in the school curriculum did not bring changes to society, students and teachers. In addition, the analysis of green technology-related curriculum syllabus in the preschool, primary and secondary schools found that the integration of green topics was not comprehensive and required updating according to the level of understanding (Laporan Kerjasama Pintar, KeTTHA, 2011).

In addition, sustainability is an important agenda in education transformation, with the aim of educating students on their responsibilities for the future of the Earth. This is important in line with studies by Johar (2013) which revealed that individual attitudes are one of the factors that contribute to this environmental problem. Environmental issues involve aspects that are closely related to the lifestyles of the community concerned with economic and material development regardless of the importance of environmental care (Mahat, 2014). This is a result of the lack of knowledge and skills in solid waste management systems, especially in waste separation management (Licy, Vivek, Saritha, Anies, \& Josphina, 2013; Festus \& Ogoegbunam, 2012).

In fact, DnT subjects equip students with practical skills that can be applied in daily life, which is valuable from the green skills aspect (Kamis et al., 2016; CEDEFOP, 2012; Azuar Ariffin, 2015). Thus, Technical and Vocational Education and Training (TVET) plays an important role in applying green skills in line with green technology; this is because industry workers involved with economic 
development are in areas such as tourism, energy sources and recycling products (UNESCO-UNEVOC, 2013). Elements of green skills should be included in technical and vocational education as an added value, so no harm would be done to the environment by people who are science and technologysensitive, hardworking, law-abiding and with integrity, in the conducts of their everyday life (Kamis et al., 2017, 2016; Mustapha, 2015; Pavlova \& Huang, 2013).

Therefore, the Gs Module in DnT subjects has been developed to provide knowledge on green skills in primary schools. This module contains three sub modules, namely Waste, Energy and Water, which relate knowledge elements to Green skills. This article aims to examine the effects of the Gs Module on the achievement of knowledge in primary schools. There are two research questions and two hypothesis in this research:

1. Is there a significant difference in pre-test knowledge of green skills between the control group and the treatment group?

2. Is there a significant difference in post-test knowledge of green skills between the control group and the treatment group?

\section{Hypothesis}

$\mathrm{H}_{\mathrm{O} 1} \quad$ There is no significant difference in the pre-test score on knowledge of green skills between the control group and the treatment group

$\mathrm{H}_{02}$ There is no significant difference in the post-test score on knowledge of green skills between the control group and the treatment group.

\section{Methodology}

This qualitative study uses a quasi-experimental technique involving two groups, which are the treatment group and control group. The experimental quasi design was chosen because the researcher could not use the full random procedure (Frankael et al., 2012; Ary, Jacobs, \& Sorenson, 2010; Noraini, 2010). In this design, the researcher provides samples from existing classes without selecting respondents randomly instead of pure experimental designs where subjects are randomly distributed in batches. The researcher uses only a sample of students in a class without disturbing and restructuring the student's position in the class according to the number of students who have been in a class.

Cluster Random sampling was used to select a sample which are a Five year pupil at a Primary school where the sample is taken on a group rather than individually (Ary, Jacobs, \& Sorenson, 2010; Idris, 2010). The samples were confirmed at the same level of knowledge in education by DnT subject teachers. Knowledge testing instruments were given to both groups before and after nine weeks of quasi experimental exercise. The treatment group was a group using the Gs Module and the control group did not use the Module (pre-test and post-test control group) (Ary et al., 2012; Donald Ary, Lucy Cheser Jacobs, \& Chris Soresen, 2009; Shadish et al., 2002).

In this study, the researcher used only two primary five classes, which involved 62 pupils: 30 students from the control group and 32 from the treatment group. Sample size was sufficient and relevant for 
a quasi-experimental study because the minimum sample size required to obtain satisfactory results in the quasi-experimental design was 30 individuals (Frankael et al., 2012; Noraini, 2010), while Creswell (2016) stated that the sample size of 15 individuals was sufficient for each group in experimental research.

\section{Instrument}

All The researcher has constructed items of knowledge test questions based Construction Basics outlined by KPM, 2014 and Eftah and Abd Aziz, (2014) according to the following steps: (1) Determine the purpose of the test; (2) Know what to test or assess; (3) Understand the philosophy, goals and curriculum content; (4) Apply the constructional theory of items; and (5) Develop the Test Specification Table. The construction of the test of achievement of knowledge testing was to measure the level of students' knowledge of green skills. Question items were adapted from Wu (2013). In addition, the Table of Specifications was built to ensure a high degree of validity of the knowledge achievement test developed by the researcher. This Table was planned according to the cognitive level of Anderson Taxonomy as proposed by the Examination Board, Ministry of Education. It also shows the number of scores per question and the scaling of the scores according to difficulty level of the questions. Hence, the construction of questions based on the Table of Specifications ensures the test items are valid (Eftah \& Abd Aziz, 2014; Nik Pa, 2014).

\section{Data Analysis}

Inference statistics are used to describe the differences or the relationship between the variables used in this study to identify the differences in the knowledge achievement test on green skills based on the group. According to Pallant (2011), the determination of the use of covariate analysis can be determined through pre-test if there is a pre-test difference between the treatment group and the control group. If there is no difference, the $t$-test analysis, the ANOVA test and the MANOVA test are used to answer the questions raised by the study.paragraphs must be indented.

In this study, independent sample tests were conducted to determine the difference between the two groups, i.e. the treatment group and the control group for the knowledge test before the learning session using the Gs Module; meanwhile, SPANOVA (Split plot ANOVA test), also known as mixed ANOVA was used to analyse the post-knowledge exam data. SPANOVA was chosen because this study fulfilled the SPANOVA test requirements, i.e. testing two independent variables (groups) on dependent variables (knowledge scores). The two groups, i.e. treatment and control groups took two tests, i.e. pre-test and post-test (also known as split plot ANOVA) with repeated measures on the second factor.

According to Pallant (2011), there are three variables involved in measuring ANOVA or SPANOVA mixed methods:

1) Having a single category of independent variables (such as group 1 / group 2, which in this study are the treatment and control groups).

2) Having one category of other independent variables (such as subject variables), such as recurring time measurements, which in this study are pre- and post-tests. 
INTERNATIONAL JOURNAL OF ACADEMIC RESEARCH IN BUSINESS AND SOCIAL SCIENCES

Vol. 8, No. 11, Nov, 2018, E-ISSN: 2222-6990 (C) 2018 HRMARS

3) Having one or more dependent variable categories, which in this study are knowledge test scores on green skills.

\section{Findings}

Table 1. Descriptive Statistics of the Knowledge Test

\begin{tabular}{|l|c|c|c|c|}
\hline & \multicolumn{2}{|c|}{ Pre-Test } & \multicolumn{2}{c|}{ Post-Test } \\
\hline Knowledge Test & $\begin{array}{c}\text { Experiment } \\
\mathrm{n}=30\end{array}$ & $\begin{array}{c}\text { Control } \\
\mathrm{n}=32\end{array}$ & $\begin{array}{c}\text { Experiment } \\
\mathrm{n}=30\end{array}$ & $\begin{array}{c}\text { Control } \\
\mathrm{n}=32\end{array}$ \\
\hline Mean & 74.9 & 77.9 & 75.9 & 95.8 \\
\hline standard deviation & 1.70 & 1.70 & 1.52 & 1.69 \\
\hline
\end{tabular}

Based on the Descriptive Statistics of the Knowledge Test shown in Table 1, the mean values of the pre-test for the control group and the treatment group are almost the same. The control group scored $74.9, \mathrm{SP}=1.70$; while the treatment group scored 75.4, $\mathrm{SP}=1.52$. This suggests that the knowledge of green skills for both groups is at a similar level, which is at a good level according to the predetermined scale. While the mean score or average post-test was carried out after the quasi experiment, and the two groups showed different values of knowledge. The treatment group scored 95.7, SP = 1.69, which is at an excellent level; while the control group scored 77.9, SP = 1.52, which is at a good levelparagraphs must be indented.

\section{Question Research 1}

Is there a significant difference in pre-test knowledge of green skills between the control group and the treatment group?

$\mathrm{H}_{\mathrm{O} 1}$ There is no significant difference in the pre-test score on knowledge of green skills between the control group and the treatment group

Table 2. Independent t-test for Knowledge Pre-Test Analysis

\begin{tabular}{|c|c|c|c|c|c|c|c|}
\hline Knowledge & $\mathrm{N}$ & Mean & $\begin{array}{c}\text { standard } \\
\text { deviation }\end{array}$ & $\begin{array}{c}\text { Levene } \\
\text { Test }\end{array}$ & & $\begin{array}{c}t- \\
\text { value }\end{array}$ & Sig \\
\hline Group & & & & $\mathrm{F}$ & Sig & & $p$ \\
\hline Experiment & 30 & 74.90 & 1.70 & 0.075 & 0.785 & -1.083 & 0.785 \\
\hline Control & 32 & 75.34 & 1.52 & & & & \\
\hline
\end{tabular}

Based on Table 2, the inferential statistical analysis of independent samples t-test shows that there is no significant difference between the control group and the treatment group with $t=(1.083)$ and sig $=0.785(p>0.05)$. This is supported by data showing that the mean values of both groups for the pre-test are almost the same; the control group ( $\min =74.90, \mathrm{SP}=1.70)$ and the treatment group ( $\min =75.34, \mathrm{SP}=1.52$ ), are considered to be at a good level. The findings of the independence sample t-test results in Question 1 show there is no significant difference in the mean score of preknowledge for students in the treatment group and the control group for knowledge prior to being 
INTERNATIONAL JOURNAL OF ACADEMIC RESEARCH IN BUSINESS AND SOCIAL SCIENCES

Vol. 8, No. 11, Nov, 2018, E-ISSN: 2222-6990 (C) 2018 HRMARS

exposed to the Gs Module. It can be concluded that the level of knowledge of the green skills possessed by both groups is almost the same, at a good level.

\section{Question Research 2}

Is there a significant difference in post-test knowledge of green skills between the control group and the treatment group?

$\mathrm{H}_{\mathrm{O} 2}$ There is no significant difference in the post-test score on knowledge of green skills between the control group and the treatment group.

To answer the above questions and hypotheses, the repeated measurements of SPANOVA tests have been carried out on knowledge variables. Knowledge scores are dependent variables while groups are independent variables in this analysis.

Table 3. SPANOVA Impact Score on the Group

\begin{tabular}{|l|l|l|l|l|l|}
\hline Effect & Huynh-Feldt & Df & F & $p$ & $\begin{array}{l}\text { Partial } \\
\text { Eta } \\
\text { Square }\end{array}$ \\
\hline Knowledge score & 4264.120 & 1 & 1672.375 & 0.00 & 0.965 \\
\hline Knowledge score *Group & 2362.508 & 1 & 926.568 & 0.00 & 0.939 \\
\hline Error & 152.984 & 60 & & & \\
\hline
\end{tabular}

The results of SPANOVA tests in Table 3 in this study use the Huynh-Feldt test. This is because in studies of social sciences and education, the Huynh-Feldt test is commonly used (Hair et al., 1998). The findings show the value of Huynh-Feldt has a significant effect on the independent variables of knowledge scores, with $[\mathrm{F}(1,60)=1672.375, \mathrm{P}<0.05]$, which are significant with Partial Eta Square, $\eta 2 p=0.965$. Meanwhile, the effect of group knowledge * interaction scores is $[F(1,60)=926.568, p$ $<0.05$ ) with a significant value in relation to Partial Eta Square, $\eta 2 p=0.939$. 


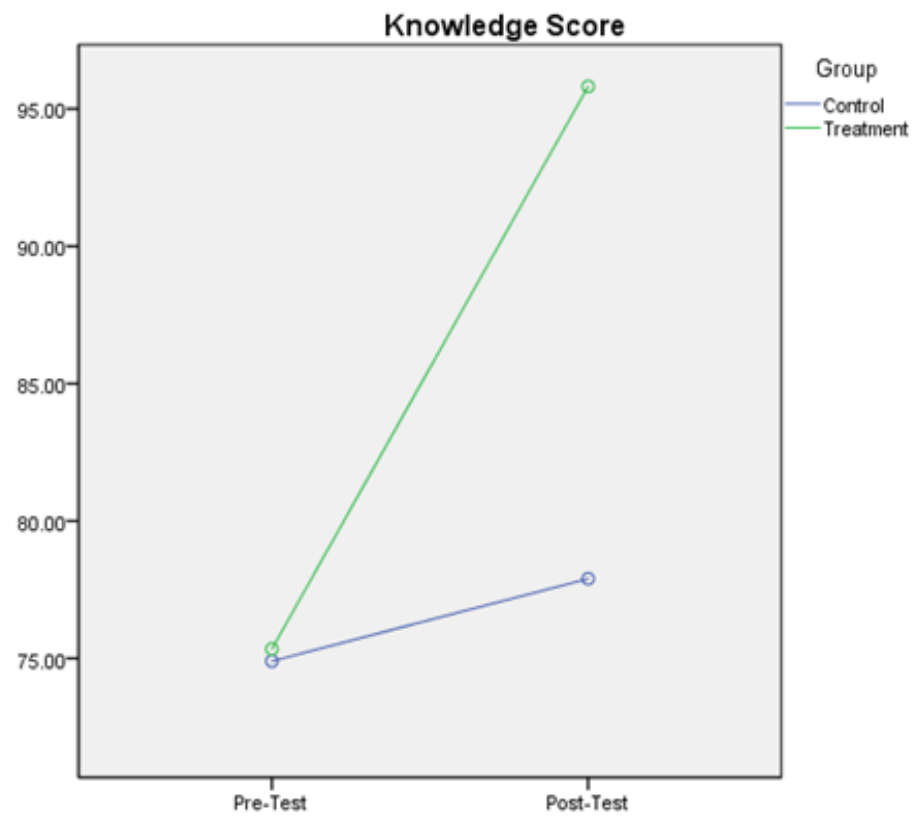

Figure 1. Knowledge Score by group

This finding is also supported by the graph as shown in Figure 1. The shape of the graph clearly shows the mean value of the treatment group using the Gs Module increasing linearly from the pre-test to the post-test. Mean knowledge scores for both control and treatment groups increase, but the treatment group show a larger increase. The knowledge score line for the treatment group using Gs Module shows a large improvement as shown by the blue line, which represents the treatment group.

\section{Discussion}

The findings of the $t$-test show that there is no significant difference in the pre-knowledge score mean for the treatment group and the control group for the knowledge aspect before the quasi experiment. This shows the level of knowledge of the students before the experiment is at the same level, which is at a good level. This shows that students have been exposed to knowledge of green skills through environmental-related activities, information obtained through reading and other means.

This finding is in line with the study conducted by Stuhmcke (2012) and a research report by UNICEFF (2011), which states that students' knowledge of green technology, global warming and elements of green skills is at high levels. This shows that students already possess the knowledge element of green skills, through the term "green practice" taught across the curriculum in the primary school curriculum. In view of this, schools also play a role in disseminating green practices where most schools have painted murals on environmental education, such as $3 R$ elements.

However, this finding is contrary to the findings of Hasnah, Dody, Noraziah, Maznah, and Sarifah (2012) regarding the knowledge of solid waste management, which is an element in green skills; the respondents' knowledge level is at a moderate level. Similarly, studies by Saravanan, Rosta, and Ahmad (2013) state that the level of knowledge on environmental sustainability, which is also a 
branch of green skills, is still at moderate level. This is in line with Teoh, (2016) which proves in its study that only one out of four schools conducts environmental education in a comprehensive manner.

The effect of the Gs Module on knowledge is addressed through Research Question 2: Is there a significant difference in the mean score of the knowledge tests after using the Gs Module for nine weeks? The findings show that the post-test treatment group's score has a significant difference; their knowledge increases to a high level; on the other hand, the control group's score remains at a good level. SPANOVA analysis also reveals that the main effect of knowledge is significant at $p<0.05$. This shows that the use of Gs Module can affect students' level of knowledge on green skills. According to Cohen (1988), the size of the effect is also large. The graph shows the mean value increases linearly from pre-test to post-test. Hence, it proves that there is a significant difference in the mean score of the knowledge test after using the Gs Module.

The findings of the module's effect on this knowledge of green skills are in line with the study by Othman, Harun, Muda, and Ismail (2013) who examined the knowledge on environmental education using mural drawing. In addition, Erdogan (2015) found that students' knowledge improved through environmentally-friendly programmes to provide knowledge of environmental education. Hence this module in the form of green skills is important in providing knowledge of the elements of green skills, which are important to future generations (Staufer, Zehrer, \& Lechner, 2012).

\section{Conclusion}

All Based on the findings of the study, the development of the Gs Module is necessary in providing the knowledge of the green skills, which are most suitable to be implemented in the skill-based subjects i.e. DnT. The implementation of the Gs Module among primary school children is relevant as they are the heirs to the earth in the future. It also provides new experiences and exposure to DnT teachers as long as this element of green skills or green concept is only integrated in Science or Geography subjects. This is in line with the fourth goal based on goals in Sustainable Development Goals (2015) to provide quality and sustainable education.

\section{Acknowledgement}

The author gratefully acknowledges the Ministry of Higher Education of Malaysia for the funding of the project FRGS (Fundamental Research Grant Scheme), 2015-0166-107-02 (FRGS/1/2015/SS109/UPSI/03/13). The author also acknowledges the constructive comments received by the anonymous reviewers

\section{Corresponding Author}

Amarumi Alwi, Faculty of Technical and Vocational Education, Universiti Pendidikan Sultan Idris, Malaysia, Email: amarumialwi@ymail.com, No 20 Jalan D Belsa 3, Taman Bandar Senawang, 70450 Seremban. 
INTERNATIONAL JOURNAL OF ACADEMIC RESEARCH IN BUSINESS AND SOCIAL SCIENCES

Vol. 8, No. 11, Nov, 2018, E-ISSN: 2222-6990 @ 2018 HRMARS

\section{References}

Alwi, A., Kamis, A., \& Ismail, B. L. H. (2018). Effects of Green Skills Module in Design and Technology Subjects on The Student's Knowledge in Primary School. International Journal of Academic Research in Business and Social Sciences, 8(11), 1701-1712. 